\title{
Evaluation of stress in dairy cows due to change in housing, milking frequency and milking equipment
}

\author{
A.M. Gadzhiev ${ }^{1 *}$, D.V. Osepchuk ${ }^{2}$, B.S. Nikkolova ${ }^{3}$, Z.A. Kubatieva ${ }^{4}$, \\ M.S. Gazzaeva ${ }^{4}$, E.F. Tsagaraeva ${ }^{5}$
}

${ }^{1}$ Federal Scientific Agroengineering Center - All-Russian Institute of Mechanization, 108823, Moscow,
Ryazanovskoye settlement, Znamya Oktyabrya settlement, 31; ${ }^{2}$ Krasnodar Research Centre for Animal Husbandry
and Veterinary Medicine, Krasnodar 350055; ${ }^{3}$ North-Ossetian State University named after K.L. Khetagurov,
Vladikavkaz, 362025; ${ }^{4}$ Gorsky State Agrarian University, 362040, Vladikavkaz, 37 Kirov Street; ${ }^{5}$ Chechen State
Pedagogical University, City Grozniy, 364068, Russian Federation.
*Corresponding author e-mail: amg-v@ bk.ru

Journal of Livestock Science (ISSN online 2277-6214) 12: 362-366

Received on 4/11/21, Accepted on 5/12/2021, Published on 25/12/21

doi. 10.33259/JLivestSci.2021.362-366

\begin{abstract}
The article deals with the issues of herd formation, including the rearing of replacement young animals, heifers and fresh cows housing, increasing the milk yield of fresh cows, the assessment of animals by the first and second lactations, formation of technological animal groups and cows milking by using various milking machines, as well as robotic milking. Due to the increased requirements for animals, when using them on large loose housing complexes and farms, and application of innovative equipment, the question of the cows stress resistance, how to prepare animals for modern equipment - robotic milkers or for automatic milking machines remains unexplored. The animal body in the adverse environment or subjected to any extreme stress feels a number of physiological reactions aimed at adapting the body to the existing conditions, at eliminating their adverse effects. The body response to the effect of external stimuli depends not only on the stimulus intensity, as well as on the animal individual characteristics, that is, on its nervous system. The aim of our research is to study the adaptive animal abilities to new conditions of innovative milking technology.
\end{abstract}

Keywords: robotic milking; nervous system; stress resistance; cow behavior; lactation. 


\section{Introduction}

The problem of increasing the gross milk production with low labor costs is the main task of agriculture in Russia. The increase in the productivity of dairy cattle breeding and the production of high-quality animal products largely depends on the herd formation, which includes the high-quality rearing of the replacement young animals with proven genetic potential in productivity and the type of higher nervous activity (Gadzhiev, 2019). It is necessary to recall the doctrine of Academician I.P. Pavlov on the types of higher nervous activity especially when introducing innovative milking technologies - robotic milking. The type of higher nervous activity significantly determines adaptive body abilities (Temiraev et al., 2012; Kokaeva et al., 2017).

The relationship directly proportional between the type of nervous system, reactivity and the level of milk productivity was established (1985). Comparing cows with different types of higher nervous activity, it was found that animals of a balanced mobile type are characterized by higher milk productivity with low-frequency fluctuations in daily milk yield (Yuldashbaev et al., 2020; Kokaeva et al., 2020).

At present, the term "stress resistance" is used to characterize cows by their reaction to changes in the external environment. Stress resistance refers to the ability to maintain a stable level of motor and secretory activity of the mammary gland when changing various technological conditions. Therefore, it is important to form herds on farms based on the type of nervous activity of cows.

The aim of the research is to study stress resistance when combining cows of different groups with a change in the way of keeping, the frequency of milking and a change of milking equipment.

\section{Materials and methods}

The experimental research involved the studies of a number of scientists on animal behavior and stress resistance. In industrial complexes, when changing technological processes, times milked per day, housing system, feeding and care, cows had alarm reactions. To study the stress state of animals when changing the method of their housing and times milked per day we used an eosinophil test to determine the eosinophil content in $1 \mathrm{ml}$ of cow blood (Ustinov, 1978). The work by T.I. Venediktova was the material to study the degree of cow motor activity in different housing systems and times milked per day (Venediktova, 1975).

Comparative analyses of various technologies for milk production, methods of animals housing, the efficiency in increasing the milk yield during the first 120 days of lactation were performed, and the possibility of cows changing from tie-stall to loose-box housing during one lactation, as well as the change from three-times-a-day milking to two-times-a-day milking was scientifically proven. At that, the animals got used to the new conditions on day 5 or day 6 after the change. The adaptation process ended on day 9.

Experimental base- To study the periods of animals' adaptation when changing the housing methods and times milked per day, the experimental research was carried out on the farms LLC "Schapovo-Sovagrotehno" and MUSP "Synkovo" in Podolsky district of the Moscow region.

The research involved four groups of 28 cows each in tie-stall and loose-box housing systems, and milking by using the milking machine "Milk pipeline". After 115 days of increasing the milk yield animals in groups I and II of tie-stall and groups III and IV of loose-box housing were all changed to loose-box one with two-times-a-day milking. The experimental design is given in Table 1. After 115 days of milk yield increase, the daily milk yield was considered, and stop-watch readings for two adjacent days before the change and for nine days after the change were performed, that is, until the behavior indicators become relatively constant.

Thus, in the industrial complexes, it is quite possible to change from tie-stall to loose-box housing and from one milking method to another per lactation. At that, the animals get used to new conditions on days 5 and 7 after the change. The adaptation process ends on day 9. When changing the technological processes in the industrial complexes, the modes of milking, housing, feeding and care, there are alarm reactions in cows. In our research, such alarm reactions (stresses) could occur when changing the housing method and the way of milking, and lasted for several days.

To study the stress state of animals during this period, we used the eosinophil test to determine the eosinophil content in $1 \mathrm{ml}$ of blood according to D.A. Ustinov (Ustinov, 1978). The eosinophil content was studied in the blood before and after changing the housing and milking method. Formula developed by T.N. Venediktova was used to characterize the intensity of motor activity (Kokaeva et al 2017)

$$
\mathrm{C}=\frac{\text { Pedometer readings }}{\text { Time of active state } *}
$$

Table 1. Experimental design

\begin{tabular}{|c|c|c|c|}
\hline \multirow[t]{2}{*}{ Groups } & \multirow{2}{*}{$\begin{array}{l}\text { Cows } \\
\text { no. }\end{array}$} & \multicolumn{2}{|c|}{ Method of housing and times milked per day by lactation periods } \\
\hline & & First 120 days & Next 185 days \\
\hline I & 28 & tie-stall housing & es/ \\
\hline II & 28 & tie-stall housing, two times/ day milking & using u \\
\hline III & 28 & loose-box housing, three times/ day milking & ne Westfalia Surge \\
\hline IV & 28 & loose-box housing, two times/ day milking & with the automatic stop device \\
\hline
\end{tabular}




\section{Results and Discussion}

During the period of increasing the milk yield, cows housed in tie-stalls rested 69.0 min more per day than the loose-housed cows (Table 2). The research results are consistent with the results obtained in the Federal Republic of Germany (Liebenberg, 1965). According to their observations, the cows housed in tie-stalls lay 59.0 min more than loose-housed cows. The research results are given in Tables $2 \& 3$.

The degree of motor activity of tie-stall housed cows in groups I and II is 1.25 and $1.55 \mathrm{steps} / \mathrm{min}$. and loose-housed cows in groups III and IV - 2.28 and 3.00 steps/min., respectively. Data in Table 2 show that in the first day after changing the housing method and times milked per day, the rest period of animals in group I decreased by $36.1 \%$, in group II - by $46.2 \%$, in group III - by $24.6 \%$ and in group IV - by $33.7 \%$.

The animals that had been trice milked before by using the linear milk pipeline took the least rest. This is due to the fact that cows got used to three-times-a-day milking and individual care. When, after increasing the milk yield, all the cows were combined into one loose-housed group, their motor activity increased: in group I - by $73.8 \%$, in group II - by $72.9 \%$, in group III - by $43.0 \%$, and in group IV - by $25.6 \%$. This excited state lasted until a certain hierarchy existed in the group. This was observed in the first 5-7 days after the combination. Then the milk yield began to increase, but did not reach the initial level. The eosinophil content change of the cow blood by groups is given in Table 4. Table 4 shows that two days before the change animals had almost the same eosinophil level in $1 \mathrm{~mm}^{3}$ of peripheral blood: in group I $-772 \pm 78$, in group II $-692 \pm 65$, in group III $-746 \pm 123$ and in group IV $640 \pm 31$. On the first day of all animals grouping into one loose-box housing section, the eosinophil number in 1 $\mathrm{mm}^{3}$ of blood decreased: in group I - by $54.5 \%$, in group II - by $49.5 \%$, in group III - by $55.3 \%$, in group IV - by $50.9 \%$. The difference is statistically significant: in group I $t d=5.08$, in group II -4.77 , in group III -3.13 and in group IV -7.13 .

The data provided show that on the first day after the change, the eosinophil content in blood decreased in groups, which were changed from the tie-stall housing. The reduced eosinophil content continued three days in the loose housing group with two-times-a-day milking and five days in the group of the same housing but milked three times a day. So, as evidenced by the literature review and the data obtained in the research, the reformation of technological groups and new animals in the sections, as well as the replacement of milking equipment is accompanied by stress.

It should be noted that the results of ethological studies on this issue are mixed. In animals of groups I and II the reduced eosinophil number in blood was observed for six to seven days and in groups III and IV - three to five days. On day 7, the eosinophil content in blood of animals from first two groups reached the initial level. This indicated the stress release caused by changes in the animal housing.

On day 2 of housing in new conditions, the eosinophil level begins increasing. Further, on day 5, it is smoothed and reaches the initial level. After the reformation and animals' adaptation to one another, follows such a situation: milk yield is restored, the rest period of animals and eosinophil content increase, which indicates the stress release.

In his work Zeeb believes that cows need at least four weeks to adapt to one another (Zeeb, 1964; Temiraev et al., 2017). Liebenberg believes that three weeks is enough to adapt (Liebenberg, 1965). Hauptman finds that the newly formed group of cows calms down in just a few days (Hauptman, 1965). Our data show that, judging by the eosinophil test, this happens on day 7.

Thus, as evidenced by the eosinophil test, the combination of cows from different groups changing the housing method, times milked per day and replacement of the milking equipment is accompanied by stress.

On the first day after grouping, replacement of the milking equipment and housing method the number of eosinophils decreased in all animals. In the first two groups (tie-stall housing), the eosinophil number is restored on day 7 and in last two groups (loose housing) - on days 3 and 5.

Table 2. Cow behaviour in tie-stall and loose housing systems

\begin{tabular}{|c|c|c|c|c|}
\hline \multirow{2}{*}{ Behavioural elements } & \multicolumn{4}{|c|}{ Groups } \\
\hline & I & II & III & IV \\
\hline \multicolumn{5}{|l|}{ Rest period, min: } \\
\hline- in boxes & $538 \pm 61.8$ & $558.2 \pm 55.6$ & $499.6 \pm 52.9$ & $482.7 \pm 41.9$ \\
\hline - on slatted floor & - & - & $23.2 \pm 13.9$ & $22.4 \pm 14.2$ \\
\hline In total & $538.6 \pm 61.8$ & $558.2 \pm 55.6$ & $552.7 \pm 48.7$ & $505.1 \pm 36.2$ \\
\hline Feed consumption, min. & $331.5 \pm 12.3$ & $334.0 \pm 7.8$ & $397.0 \pm 14.0$ & $363.2 \pm 14.9$ \\
\hline \multicolumn{5}{|l|}{ Displacement, times: } \\
\hline - during feeding & - & - & $1.9 \pm 0.6$ & $1.9 \pm 0.3$ \\
\hline - from boxes & - & - & $1.3 \pm 0.5$ & $0.8 \pm 0.3$ \\
\hline Fights, times & - & - & $1.3 \pm 0.5$ & $1.9 \pm 0.6$ \\
\hline Stand, min. & $556.1 \pm 6.3$ & $530.3 \pm 56.2$ & $484.4 \pm 38.4$ & $533.0 \pm 40.2$ \\
\hline $\begin{array}{l}\text { Milking, including bringing and } \\
\text { driving off the milking area, min. }\end{array}$ & $13.8 \pm 0.8$ & $17.7 \pm 0.9$ & $35.9 \pm 1.3$ & $38.7 \pm 1.5$ \\
\hline The time taken to milking, min. & - & - & $10.6 \pm 0.6$ & $12.8 \pm 0.9$ \\
\hline Motor activity, steps & $429.9 \pm 21.5$ & $544.3 \pm 39.7$ & $986.4 \pm 85.7$ & $1202 \pm 90.8$ \\
\hline
\end{tabular}


Table 3. Cow behaviour to different housing method (the first day after change)

\begin{tabular}{|c|c|c|c|c|}
\hline \multirow{2}{*}{ Behavioural elements } & \multicolumn{4}{|c|}{ Groups } \\
\hline & I & II & III & IV \\
\hline \multicolumn{5}{|l|}{ Rest period, min: } \\
\hline- in boxes & $314.1 \pm 41.3$ & $276.8 \pm 39.7$ & $355.0 \pm 30.2$ & $316.8 \pm 2.7$ \\
\hline - on slatted floor & $30.0 \pm 23.2$ & $23.6 \pm 12.1$ & $38.6 \pm 25.7$ & $18.2 \pm 7.7$ \\
\hline In total & $344.1 \pm 39.7$ & $300.5 \pm 36.4$ & $393.2 \pm 27.3$ & $335.0 \pm 31.4$ \\
\hline Feed consumption, min. & $275 \pm 11.8$ & $268.0 \pm 12.1$ & $297.7 \pm 7.9$ & $303.0 \pm 10.4$ \\
\hline \multicolumn{5}{|l|}{ Displacement, times: } \\
\hline - during feeding & $5.6 \pm 1.5$ & $4.7 \pm 1.14$ & $1.5 \pm 0.5$ & $3.6 \pm 0.6$ \\
\hline - from boxes & $1.3 \pm 0.3$ & $1.8 \pm 0.4$ & $0.6 \pm 0.3$ & $0.6 \pm 0.3$ \\
\hline Fights, times & $2.7 \pm 0.3$ & $2.4 \pm 0.5$ & $0.8 \pm 0.3$ & $1.6 \pm 0.5$ \\
\hline Stand, min. & $783.8 \pm 39.9$ & $834.5 \pm 32.3$ & $712.1 \pm 24.9$ & $765.0 \pm 31.2$ \\
\hline $\begin{array}{l}\text { Milking, including bringing and } \\
\text { driving off the milking area, min. }\end{array}$ & $37.0 \pm 1.3$ & $37.0 \pm 1.2$ & $37.0 \pm 1.3$ & $37.0 \pm 1.3$ \\
\hline The time taken to milking, min. & 1.7 & 1.7 & 1.7 & 1.7 \\
\hline Motor activity, steps & $1643.4 \pm 180.5$ & $2010.5 \pm 115.9$ & $1730.8 \pm 103.7$ & $1615.2 \pm 85.5$ \\
\hline
\end{tabular}

Table 4. Change in the eosinophil content per $1 \mathrm{~mm}^{3}$ of cow blood, pcs.

\begin{tabular}{|c|c|c|c|c|c|c|}
\hline \multirow{2}{*}{ Groups } & \multirow{2}{*}{$\begin{array}{c}\text { Blood collection, } \\
\text { day }\end{array}$} & \multicolumn{3}{|c|}{ Eosinophil number } & \multirow{2}{*}{$\begin{array}{l}\text { Eosinophil, \% decline } \\
\text { post change }\end{array}$} & \multirow{2}{*}{$t d$} \\
\hline & & $\mathrm{M} \pm \mathrm{m}$ & $\sigma$ & $\mathrm{C}_{\mathrm{v}}$ & & \\
\hline \multirow{4}{*}{$\begin{array}{l}\text { I } \\
\text { tie-stall housing, } \\
\text { two-times-a-day } \\
\text { milking }\end{array}$} & Before grouping: & $772 \pm 73$ & 253.0 & 33.4 & - & \\
\hline & After grouping: & & & & & \\
\hline & - day 1 & $352 \pm 28$ & 91.3 & 26.1 & -54.4 & 5.08 \\
\hline & - day 2 & $424 \pm 44$ & 144.9 & 34.2 & -45.1 & 3.89 \\
\hline \multirow{4}{*}{$\begin{array}{l}\text { II } \\
\text { tie-stall housing, } \\
\text { three-times-a-day } \\
\text { milking }\end{array}$} & Before grouping: & $692 \pm 65$ & 215.9 & 31.2 & - & \\
\hline & After grouping: & & & & & \\
\hline & - day 1 & $350 \pm 30$ & 100.1 & 28.6 & -49.5 & 4.77 \\
\hline & - day 2 & $392 \pm 46$ & 151.0 & 38.5 & -43.4 & 3.78 \\
\hline \multirow{4}{*}{\begin{tabular}{|l} 
III \\
loose housing, \\
two-times-a-day \\
milking
\end{tabular}} & Before grouping: & $746 \pm 123$ & 407.4 & 54.6 & - & \\
\hline & After grouping: & & & & & \\
\hline & - day 1 & $333 \pm 49$ & 161.9 & 48.7 & -55.4 & 3.13 \\
\hline & - day 2 & $390 \pm 43$ & 143.4 & 36.8 & -47.7 & 2.74 \\
\hline \multirow{4}{*}{$\begin{array}{l}\text { IV } \\
\text { loose housing, } \\
\text { three-times-a-day } \\
\text { milking }\end{array}$} & Before grouping: & $640 \pm 31$ & 101.4 & 16.2 & - & \\
\hline & After grouping: & & & & & \\
\hline & - day 1 & $314 \pm 31$ & 103.5 & 33.0 & -50.9 & 7.13 \\
\hline & - day 2 & $358 \pm 30$ & 99.7 & 27.9 & -44.1 & 6.22 \\
\hline
\end{tabular}

Conclusion In the industrial complexes, it is quite possible to change from tie-stall to loose-box housing and from one milking method to another per lactation. At that, the animals get used to new conditions on days 5 and 7 after the change. The adaptation process ends on day 9.

As evidenced by the eosinophil test, the combination of cows from different groups changing the housing method, times milked per day and replacement of the milking equipment is accompanied by stress. According to our research, the cows adapt to one another on day 7.

\section{References}

1). Gadzhiev A.M. 2019Influence of milking technology on milk quality. Journal of VNIIMZH. 1: 116-120.

2). Hauptman J. 1965. Prispevek etologii stotusezretelem na denni a sezonni periodicity a velkovyrolinchovu.Zivocisntechnologii vyroba, 10(9): 641-654.

3). Kokaeva, M.G., Temiraev, R.B., Beslaneev, E.V., Cherchesova, S.K., Kubatieva (Gutieva), Z.A. and Kozyrev, S.G. 2017. Influence of antioxidant and adsorbent on the processes of digestive and intermediate metabolism in lacting cows during denitrification. Journal of Pharmaceutical Sciences and Research. 9(12): 2401-2404.

4). Kokaeva M.G., Temiraev R.B., Dzhaboeva A.S., Osikina R.V., Gazzaeva M.S., Shugusheva L.H., Sattsaeva I.K., Nerovnykh L.P., Arutyunova G.Y., Efendiev B.S. 2020. Method for increasing the ecological and food values of milk and dairy products. Journal of Livestock Science 11: 14-19.

5). Kokorina E.P. 1985. Changes in milk productivity with different types of nervous activity. Journal of L.K. Ernst Federal Research Center for Animal Husbandry 1: 110-112.

6). Liebenberg O. 1965. Phisiologische und phsycologische Fragen bei der Haltung von Rinder in Grosbestanden.Tierzucht, 19(9): 490-496.

7). Temiraev R.B., Kozyrev S.G., Kononenko S.I., Baeva A.A., Bobyleva L.A. and Kalabekov A.L. 2017. Impact of the breed-specific characteristics on the metabolism and heavy metal accumulation in the organs and tissues of calves. Journal of Pharmaceutical Sciences and Research 9(6): 780-784. 
8). Temiraev R.B. Vityuk L.A., Kokaeva M.G., Djibilova N.S., Kanukov A.M. 2012. A way to improve the consumer qualities of Ossetian cheese. Proceedings of Gorsky State Agrarian University, Vladikavkaz 49(3): 169-173.

9). Ustinov D.A. 1978. Methodological recommendations to determine the stress development in animals using the eosinophil test. Dubrovitsy, ONTI, 3-24.

10). Venediktova T.N. 1978. Methods to study the cattle behaviour. Methodological recommendations to study behaviour of farm animals. L. Issue 1. P. 35-42.

11). Yuldashbaev Y.A., Temiraev R.B., Tedtova V.V., Temiraev K.B., Osikina R.V., Gazzaeva M.S., Shugusheva L.H., Sattsaeva I.K., Udychak M.M. 2020. Journal of Livestock Science 11: 8-13.

12). Zeeb K. 1964. Verhaltensforschung und Haustieerhaltung. - Tierzuchter, 16, 3: 74-76.

A.M. Gadzhiev, D.V. Osepchuk, B.S. Nikkolova, Z.A. Kubatieva, M.S. Gazzaeva, E.F. Tsagaraeva 2021. Evaluation of stress in dairy cows due to change in housing, milking frequency and milking equipment Journal of Livestock Science (ISSN online 2277-6214) 12: 362-366 doi. 10.33259/JLivestSci.2021.362-366 